\title{
Procyclicality in Central Bank Reserve Management: Evidence from the Crisis
}

Jukka Pihlman and Han van der Hoorn 
IMF Working Paper

Monetary and Capital Markets Department

\title{
Procyclicality in Central Bank Reserve Management: Evidence from the Crisis
}

Prepared by Jukka Pihlman and Han van der Hoorn ${ }^{1}$

Authorized for distribution by Udaibir S. Das

June 2010

\begin{abstract}
This Working Paper should not be reported as representing the views of the IMF.

The views expressed in this Working Paper are those of the author(s) and do not necessarily represent those of the IMF or IMF policy. Working Papers describe research in progress by the author(s) and are published to elicit comments and to further debate.

A decade-long diversification of official reserves into riskier investments came to an abrupt end at the beginning of the global financial crisis, when many central bank reserve managers started to withdraw their deposits from the banking sector in an apparent flight to quality and safety. We estimate that reserve managers pulled around US\$500 billion of deposits and other investments from the banking sector. Although clearly not the main cause, this procyclical investment behavior is likely to have contributed to the funding problems of the banking sector, which required offsetting measures by other central banks such as the Federal Reserve and Eurosystem central banks. The behavior highlights a potential conflict between the reserve management and financial stability mandates of central banks. This paper analyzes reserve managers' actions during the crisis and draws some lessons for strategic asset allocation of reserves going forward.
\end{abstract}

JEL Classification Numbers: E58; G01; G11; G15; G21; G32.

Keywords: Central banks; financial crises; financial stability; reserve management; risk management.

Authors’ E-Mail Addresses: jpihlman@imf.org; hvanderhoorn@imf.org.

\footnotetext{
${ }^{1}$ Sovereign Asset and Liability Management Division, Monetary and Capital Markets Department, IMF. We thank Graham Colin-Jones, Reginald Darius, Udaibir S. Das, Antonio Galicia-Escotto, Simon Gray, Kai Guo, John Kiff, Peter Kunzel, Yinqiu Lu, Christian Mulder, Michael Papaioannou, Joonkyu Park, and Henrik Schwartzlose for their comments. We would also like to thank seminar participants at the 2009 Joint BIS/ECB/World Bank Public Investors' Conference in Washington, D.C., and at the 2010 BIS Meeting on Reserve Management in Kampala (Uganda). All errors and omissions remain our sole responsibility.
} 


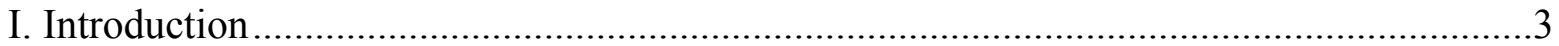

II. Reserve Management Objectives ............................................................................4

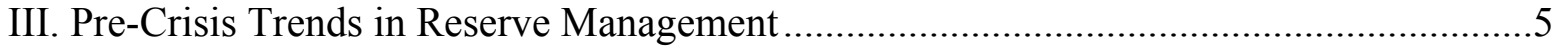

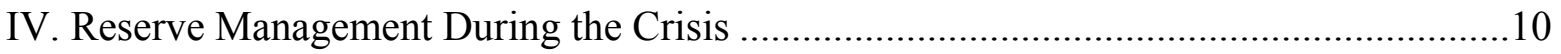

A. Survey Results and Anecdotal Evidence ............................................................ 10

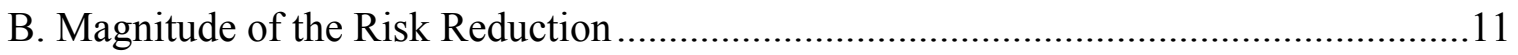

C. Procyclicality in Credit Limit Frameworks ............................................................... 17

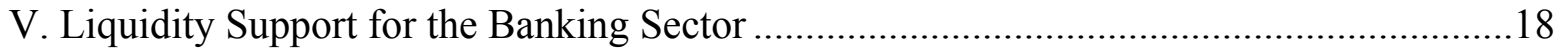

VI. Reserve Management and Financial Stability ..........................................................20

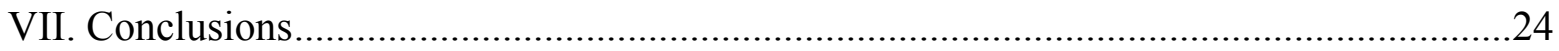

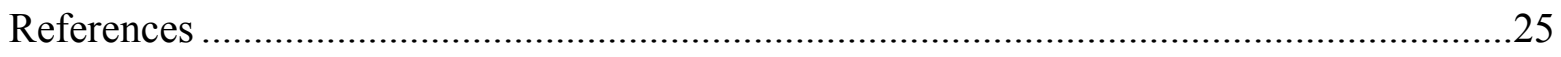

Figures:

Figure 1. Trends in Level and Growth of Reserves (Excluding Gold) ................................5

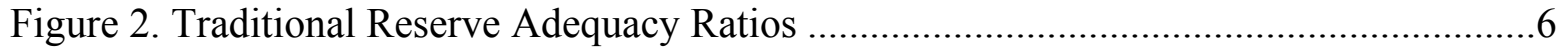

Figure 3. Reserves vs. Short-Term Government Debt ...................................................... 7

Figure 4. Reserve Management Trends ................................................................... 8

Figure 5. Currency Composition of Official Reserves (All Reporting Countries) .................9

Figure 6. Central Bank Reserves Held as Bank Deposits ................................................13

Figure 7. Distribution of the Decline of Bank Deposits as a Share of Reserves...................14

Figure 8. Change in Bank Deposits vs. Change in Reserves ............................................14

Figure 9. Central Bank Reserves Invested in Bank Deposits and Reverse Repos...................15

Figure 10. Liquidity Measures Approximated by Changes in Central Bank Claims on the

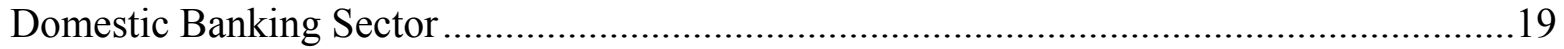

Figure 11. Deposit Reduction vs. LIBOR - OIS Spread..............................................21 


\section{INTRODUCTION}

Central banks provide funding to the banking sector mainly through two distinct channels. Through the first channel — regular monetary refinancing operations - they provide liquidity to domestic banks. The second channel-less well known, but still significant—pertains to central banks investing official reserves in short-term bank deposits and possibly securities of foreign banks. This second channel can be an important source of funding, especially for large international banks located in countries that issue reserve currencies. Until the start of the global financial crisis in 2007, a large share of central bank reserves was held in deposits with such banks. Although on average small in comparison with other sources of funding - notably consumer deposits and wholesale funding - the amounts were significant in absolute terms, and were typically concentrated in the largest banks. While it is true that these banks could have used other sources of funding, central bank reserves provided an attractive and - until the crisis — stable funding source.

When the crisis hit, many central banks withdrew these investments, in some cases rather abruptly, in ways very similar to commercial asset managers. Traditionally very conservative investors, with a low appetite for risk, the crisis response of reserve managers was perhaps unsurprising — and from an individual reserve manager's perspective even rational - yet the withdrawal of central bank investments also put further pressure on the banking sector when other sources of funding dried up simultaneously and spreads exploded. In some countries, the withdrawal was unavoidable, as reserves were urgently needed for intervention or to finance domestic support measures during the crisis. In most countries, though, reserves were not used, or the amount used was much smaller than the withdrawal of investments from the banking sector. In each case, and certainly in aggregate, reserve managers acted very procyclically, and may well have been in conflict with the more prominent financial stability objectives of the central bank. Through such behavior, reserve managers may have contributed, albeit unintentionally, to the funding problems in some banks, and have forced an even stronger policy response by the authorities in countries issuing a reserve currency (see e.g., McGuire and von Peter, 2009, for an analysis of the problems and response in the U.S. dollar markets).

The procyclical behavior of reserve managers raises several important questions about the role of reserve management not only during a crisis, but in normal times as well. Unlike the link between reserves and crisis prevention, the role of reserve management in relation to financial crises has received little attention in the literature, ${ }^{2}$ although a number of senior central bankers have flagged some of the potential conflicts in recent speeches. In this paper we aim to address the main issues, focusing in particular on the magnitude of investments withdrawn, and the possible explanations for and implications of procyclical reserve management. We provide estimates of the amount withdrawn by reserve managers from the private sector, and compare this amount with central bank support measures provided to

\footnotetext{
${ }^{2}$ Indeed, the IMF's own "Guidelines for Foreign Exchange Reserve Management," published in 2001, do not cover procyclicality, even though they were part of a broader work program to promote policies and practices that contribute to (financial) stability. The Guidelines are, however, very clear on the priorities of reserve management (see Section II).
} 
domestic markets at around the same time. We investigate the reasons and justifications for the behavior of reserve managers. We argue that, at a minimum, reserve management should not interfere with the policy objectives of its own central bank and those of other central banks and, ideally, should reinforce them. This has important implications for the strategic asset allocation of central banks.

The remainder of this paper is organized as follows. After a brief overview of central bank reserve management objectives in Section II, Section III summarizes the main trends in reserve management that existed before the crisis. In Section IV, we review reserve managers' actions during the crisis, which we compare in Section $\mathrm{V}$ with the extraordinary liquidity support provided by some central banks at around the same time. In Section VI, we discuss some of the links between reserve management and financial stability. Section VII concludes.

\section{RESERVE MANAGEMENT OBJECTIVES}

Central bank reserves are held for a variety of reasons. Most of these reasons can be captured under the umbrella of "self-insurance" against financial shocks and sudden stops in the access to international capital markets, and enhancing the credibility of monetary policy. As a result, reserves have traditionally been held in liquid, short-duration government bills and bonds, denominated in a handful of reserve currencies, predominantly the U.S. dollar and euro (and earlier in its main legacy currencies).

In line with the overarching objectives for reserves and the core tasks of the central bank, the role of the reserve management function is to ensure that reserves are invested prudently, such that they are readily available when needed, while generating a reasonable return over the long run. ${ }^{3}$ The objectives of reserve management are formulated in the IMF's Guidelines for Foreign Exchange Reserve Management (2001): "Reserve management should seek to ensure that (1) adequate foreign exchange reserves are available for meeting a defined range of objectives; (2) liquidity, market, and credit risks are controlled in a prudent manner; and (3) subject to liquidity and other risk constraints, reasonable earnings are generated over the medium to long term on the funds invested."

Reserves and the reserve management function are directly linked to the core tasks of a central bank, namely ensuring price and financial stability. ${ }^{4}$ Adequate reserve levels can reassure markets that a country can meet its foreign currency obligations, thereby reducing the probability of a crisis, and weather the impact of a crisis, should one occur.

\footnotetext{
${ }^{3}$ In this paper, the "reserve management function" or, in short, "reserve management" refers to the functional areas - excluding the Board level-inside the central bank responsible for the composition (asset allocation) of the foreign reserves. It includes the portfolio as well as risk management area, i.e. front as well as middle office.

${ }^{4}$ In some countries - e.g., Canada, Japan, the United Kingdom, and the United States - reserves are managed by the central bank, but owned (at least partially) by the ministry of finance, which may decide on their usage. This set-up could complicate the linkages. In this paper, we do not distinguish reserves by ownership structure.
} 


\section{Pre-Crisis Trends in Reserve Management}

Of the various trends in reserves and reserve management over the last decades - e.g., reserve accumulation, gold sales - we concentrate on the increased focus on return and the corresponding shift out of government bonds. By and large, for most central banks, this shift started around the turn of the century. Before that, reserve management was predominantly liquidity driven and return played a very minor role in the portfolio composition. While it is true that the share of bank deposits and private money market instruments in U.S. dollar reserves started to increase already in the mid-1970s (McCauley and Fung, 2003), part of this earlier shift can be explained by a rapid growth of reserves in emerging and developing countries, many of which did not have the capacity to manage a securities portfolio. Note that the reserves growth in these countries was even more pronounced then than it is today (Figure 1).

\section{Figure 1. Trends in Level and Growth of Reserves (Excluding Gold)}

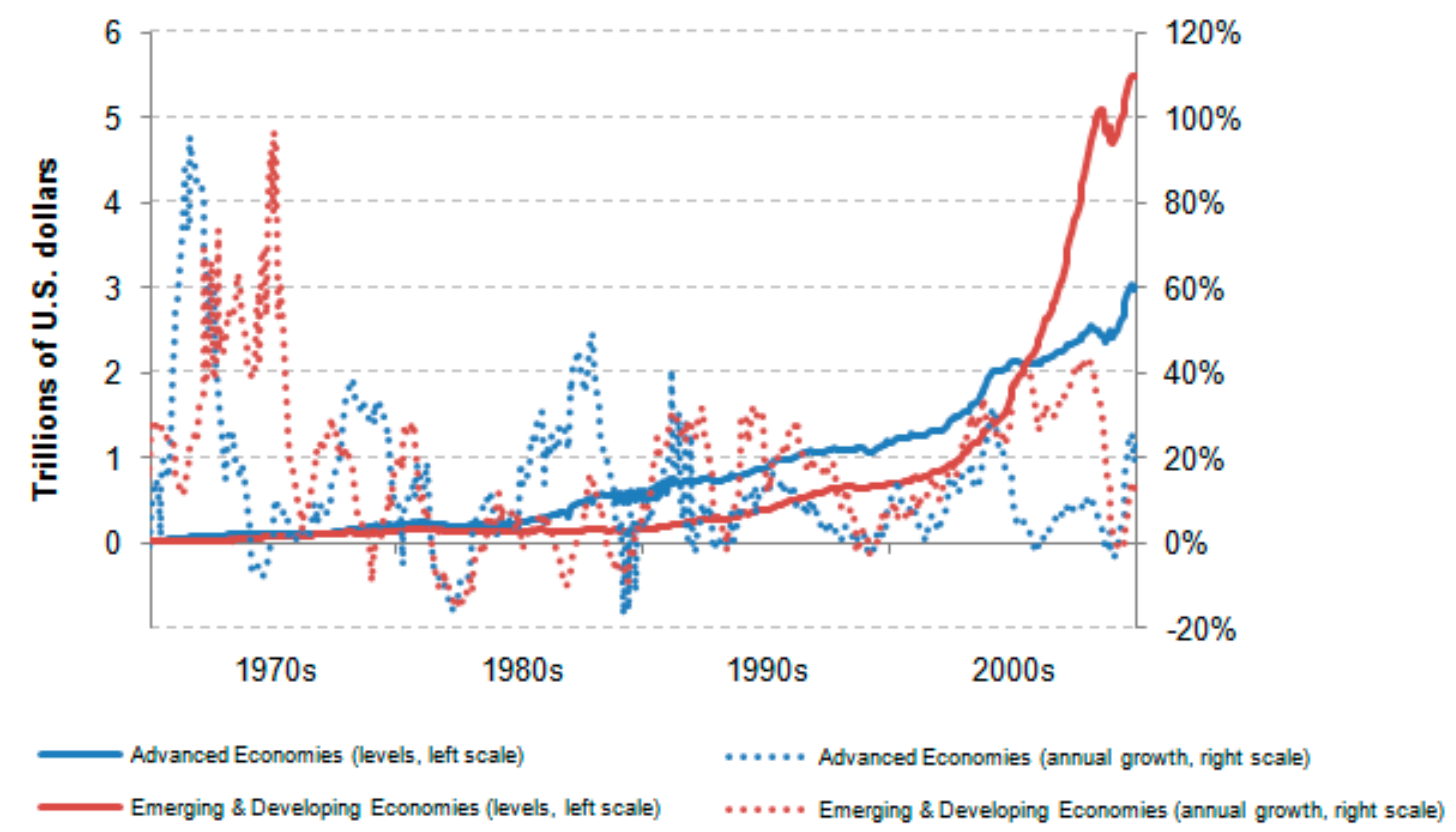

Source: IMF, International Financial Statistics.

The asset classes that benefited most from the diversification out of government bonds were agency securities and deposits, indicating that central banks were accepting substantially more credit risk. Some central banks also invested in equities. Although data remain incomplete, these trends are well documented in a number of papers and books, e.g., McCauley and Fung (2003), Wooldridge (2006), Bakker and van Herpt (2007), and Borio, Galati, and Heath (2008). Surveys conducted by Central Banking Publications since 1999 (the first one published in 2000) provide valuable additional insight, mainly of a qualitative nature. Since 2005 these surveys have been published annually in Reserve Management Trends (RMT). Last but not least, central banks themselves are disclosing - slowly, but surely - more and more information about their reserve management activities typically in their annual reports. 
Figure 2. Traditional Reserve Adequacy Ratios

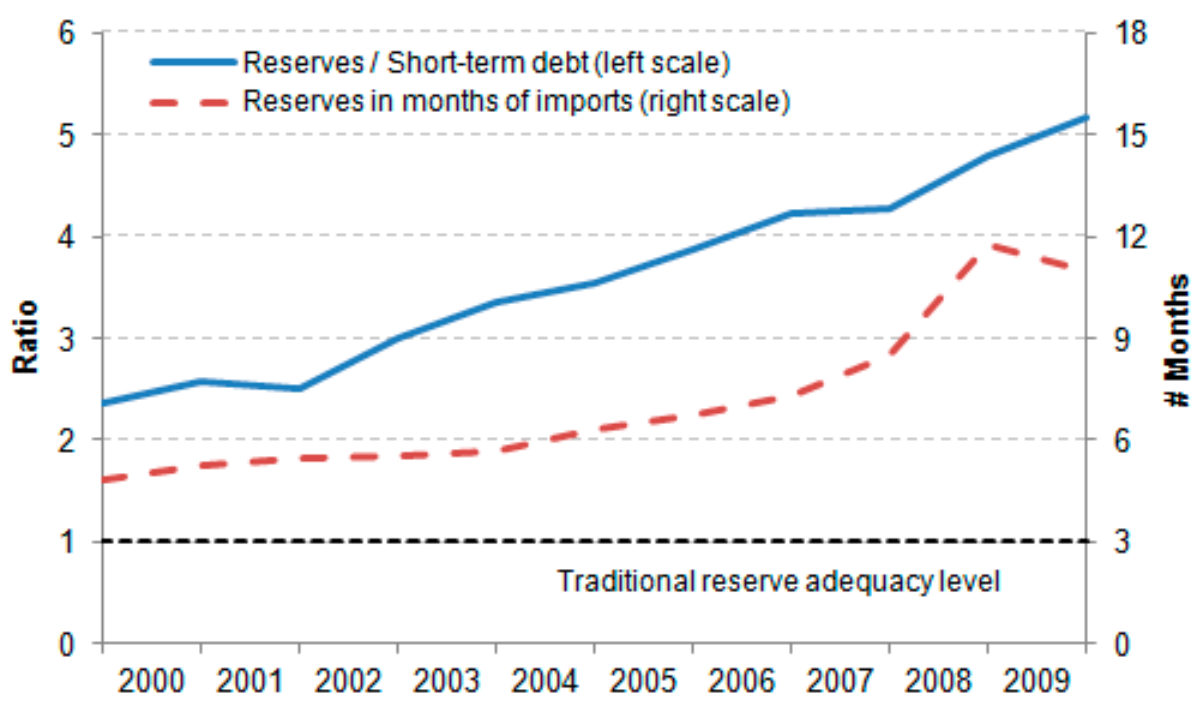

Source: IMF, World Economic Outlook.

The diversification of central bank reserves was driven by a combination of factors. Firstly, global reserves were growing rapidly, in particular after the Asian crisis, from US $\$ 1.8$ trillion in 1998 (year-end) to US\$8.5 trillion 11 years later (reserves excluding gold), and reserve adequacy ratios increased accordingly (Figure 2, which shows the evolution of two commonly used ratios for emerging and developing economies). ${ }^{5}$ Although driven by precautionary motives in many countries, surplus reserves were increasingly managed as a store of national wealth. A special case was formed by the national central banks (NCBs) of the euro area, whose reserves became only a second line of defense after the establishment of the European Central Bank (ECB), reducing the need to hold reserves in the most liquid instruments at the national level. Secondly, low interest rates led to a global search for yield, in which also central banks participated.

It seems difficult to imagine today, but a third factor of importance was that the United States had had a budget surplus since 1998, which was projected to grow, suggesting that the U.S. government debt might rapidly disappear (see e.g., Congressional Budget Office, 2000; Reinhart and Sack, 2000). Similar projections were made for many other countries. Although the surplus did not persist long, the period was long enough to force reserve managers to think about alternatives to government debt. Moreover, the outlook then still has relevance today, as the level of official reserves exceeded the supply of short-term government debt in the main reserve countries - i.e., the "preferred habitat" of many central banks - throughout the last five years. The global financial crisis temporarily narrowed the gap, but did not close

\footnotetext{
${ }^{5}$ The most widely used indicators for reserve adequacy are short-term debt with a (remaining) maturity of up to 12 months, and 3 months worth of imports. The former - also known as the Greenspan-Guidotti rule - is relevant if the country's main vulnerability is a shock to the current account, while the latter is preferred if the country is exposed to a reversal of the capital account.
} 
it (Figure 3). Other reasons for the diversification of central bank reserves include the professionalization of the reserve management function, and the notion that a central bank needs to have at least some investments in systemically important asset classes such as mortgage-backed securities in order to be able to fully understand their features and the functioning of the market.

\section{Figure 3. Reserves vs. Short-Term Government Debt}

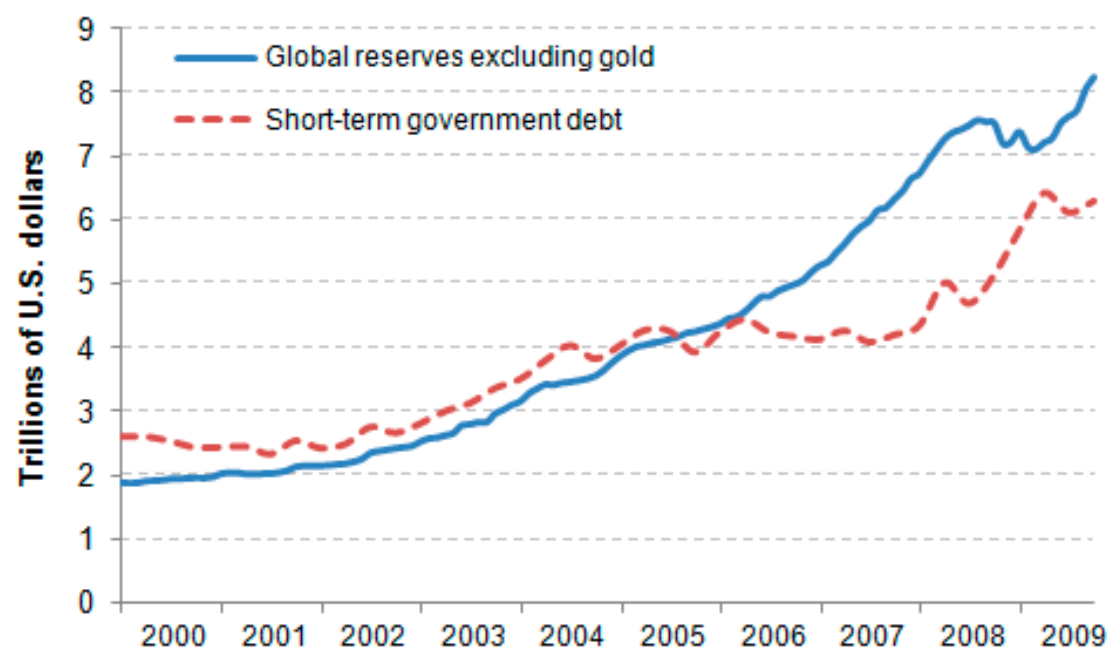

Sources: IMF, International Financial Statistics (for reserves); BIS, Securities Statistics (for short-term debt).

Note: Included in the calculation of short-term government debt are the major and most liquid issuers in currencies of the SDR basket, i.e., the United States Japan, United Kingdom, and for the euro area Germany and France. Short term is defined as securities with a remaining maturity less than one year.

More often than not, the diversification of reserves was driven primarily by a search for yield, as illustrated by, among other things, the annual RMT surveys. In these surveys, diversification was equated almost exclusively to higher expected returns, while the traditional diversification argument_risk reduction_-played only a minor role. Figure 4 illustrates these survey results through a few illustrative but representative phrases from RMT and its predecessor "How Countries Manage Reserve Assets" (HCMRA), which are set against market yields and spreads at the times these surveys were conducted. The vertical bars in Figure 4, which represent these surveys, are placed at year-end, i.e., roughly inbetween the survey dates (in the fall) and their publication dates (around February of the following year). It is particularly striking to see that in the 2007 survey-conducted in late-2006, when the Federal Funds rate had reached its highest level (5.25 percent) since February 2001, and investment grade spreads were at their lowest level ever-reserve managers still used the low-yield environment as an argument for diversification. 
Figure 4. Reserve Management Trends

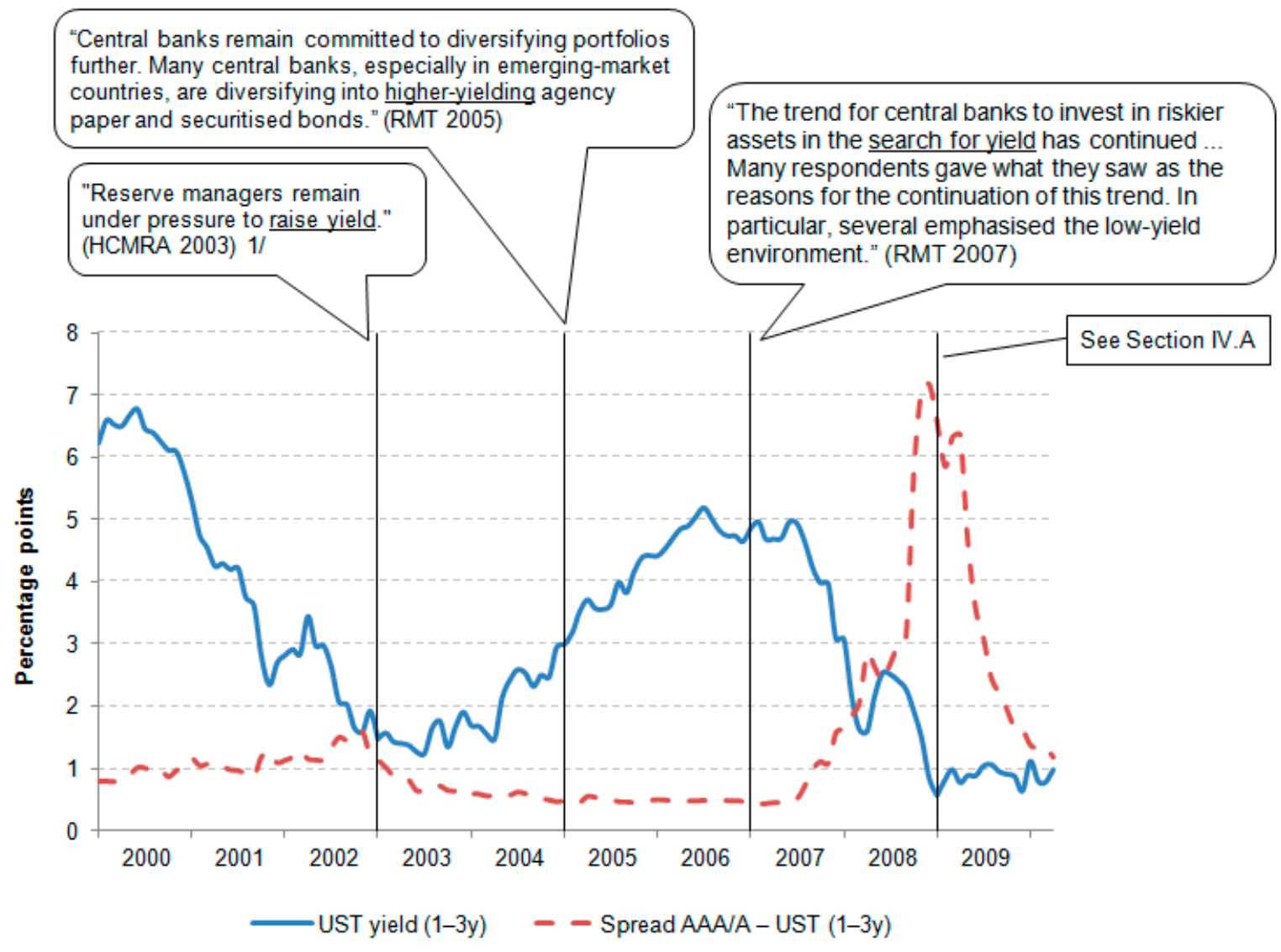

Sources: Merrill Lynch (Bloomberg indices C110 and G1O2); Central Banking Publications (emphasis added).

$1 /$ Note that this survey appears to have been held mainly among portfolio managers at central banks. Only one year later, in New Horizons in Central Bank Risk Management, the same authors document findings from a survey among risk managers, at presumably the same or similar central banks, that: "Despite the pressure on income, central bankers generally remain extremely conservative in their attitudes towards further diversification of their portfolios-mainly for good risk-management reasons."

In contrast, there is little evidence of currency diversification in the last 10 years. As the size of reserves increased, a shift towards a domestic numeraire currency would have been plausible. The (limited) evidence available suggests that such a shift may indeed have taken place (Borio, Galati, and Heath, 2008; McCauley, 2008). Under such a scenario,

diversification out of the U.S. dollar is to be expected, as the share of the dollar in global reserves far exceeds its market capitalization weight in global fixed income markets. Hence, currency diversification would have reduced exchange rate risk. However, this has not yet happened, at least not in meaningful amounts. Some reallocation obviously took place after the creation of the euro, but over the period 2003-09, the aggregate share of the U.S. dollar has remained remarkably stable at around 60 percent of global reserves (Figure 5). ${ }^{6}$ Likewise,

\footnotetext{
${ }^{6}$ Note that the claims about the currency composition are based on an incomplete sample of countries. The COFER database represents approximately 60 percent of global reserves.
} 
the euro share has fluctuated in a narrow band around 30 percent of overall reserves. In other words, currency reallocations by central banks were primarily driven by rebalancing, following exchange rate movements and reserve accumulation. Diversification took place in other dimensions: from very short to slightly longer maturities, and from government to nongovernment bonds and sometimes equities, i.e., into instruments with higher expected returns.

\section{Figure 5. Currency Composition of Official Reserves (All Reporting Countries)}

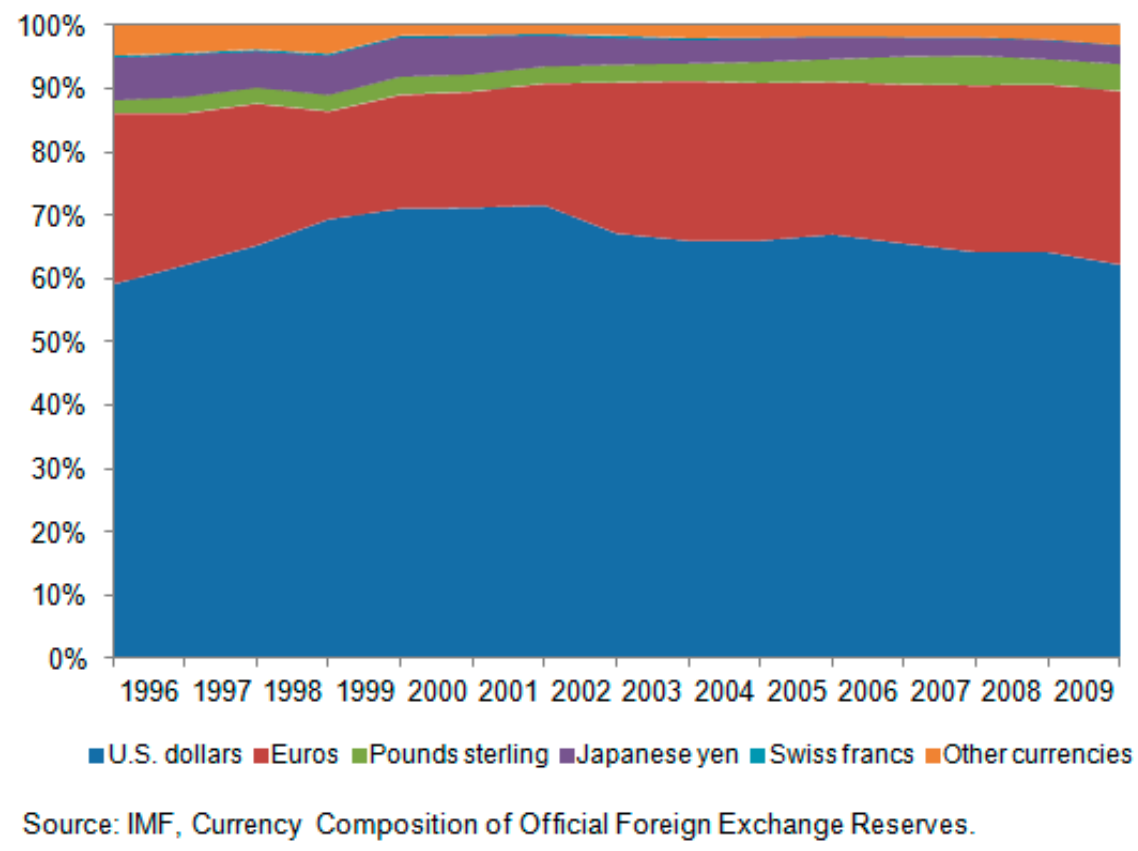

It is plausible that central banks' search for yield was further encouraged by benchmarking of investment performance, not only against a predefined benchmark, but of central banks against each other as well. A good example of this is the case of the ECB's foreign reserves, which are managed by the euro area NCBs against a common benchmark (since 2006 with currency specialization). Bourquin and Marton (2009) explain how NCBs managing ECB reserves are ranked by performance. Implicitly, NCBs are thus benchmarked against each other. Clearly, this type of competition among central banks creates an environment which puts more emphasis on return — note that the ranking is not based on risk-adjusted returnand stimulates creativity for return-enhancing investment strategies.

When reserve managers diversified into credit products, a key assumption was that central banks, as long-term investors, could, if needed, hold assets until maturity. Moreover, historical default rates suggested that default risk for investment grade assets was very remote, so that the additional risk of non-government securities was primarily spread risk. Together with the classical and popular mean-variance approach, ${ }^{7}$ this led to the false belief

\footnotetext{
${ }^{7}$ For a good overview of some of the pitfalls of mean-variance, as well as a possible refinement, see Fernandes and Ornelas (2010).
} 
that the credit spread was a more than adequate compensation for the additional risk. ${ }^{8}$ Several papers, mostly written by investment banks, went as far as suggesting that the marginal risk contribution of investment grade credit to a reserves portfolio invested in government bonds would be negative, thanks to a negative correlation of spreads and government bond yields. Under these assumptions, it appeared hard to resist the seemingly free lunch of credit or spread products. ${ }^{9}$

The search for yield also manifested itself in the creation of sovereign wealth funds (SWFs), many of which were established in the last decade. SWFs come in various shapes and forms, but a common denominator is that they are typically not restricted by the liquidity requirements of the central bank and that they, as a consequence, can put greater emphasis on return, although their strategic asset allocations depend on their objectives (see e.g., IMF, 2008; Kunzel and others, forthcoming).

\section{Reserve Management During the Crisis}

\section{A. Survey Results and Anecdotal Evidence}

As the crisis unfolded, many central banks joined the flight to quality and liquidity, reducing their exposure to non-government issuers and counterparties. The risk reduction was achieved through a combination of active and semi-active investment strategies. An active strategy involves liquidating risky assets, while semi-active refers to a strategy whereby assets are held until maturity and then reinvested in safer assets. The data do not permit a breakdown of the risk reduction into active and semi-active contributions, and these are therefore analyzed collectively.

An indication of the extent to which central banks reduced credit exposures (semi-)actively is found in the RMT 2009 survey. No less than 76 percent of central banks responding to the questionnaire reduced credit limits in response to the crisis. An even larger share, 85 percent, reduced the maximum maturity of deposits, allowing them to withdraw money at shorter notice, if and when needed. Quite a few central banks also reduced their securities lending activities. RMT 2009 summarizes these findings as follows: "Central banks joined the flight to quality, cutting deposit holdings, tightening credit limits for assets, reducing exposure to counterparties and emphasizing traditional assets, notably top-rated government bonds and gold."

\footnotetext{
${ }^{8}$ The seemingly wide credit spread became a "puzzle" to many investors. Amato and Remolona (2003) argue that this puzzle was in essence a compensation for a lack of diversification possibilities.

${ }^{9}$ Ramaswamy (2008) puts the pre-crisis potential revenues in some perspective. Using a sample of emerging market economies, he estimates that an increase in duration from 1-3 years to 1-10 years reduces the costs of holding reserves by approximately 0.0 to 0.3 percent of GDP (depending on the country and the assumed currency distribution). Increasing the duration even further (to 1-30 years) and mixing fixed income with equities reduces costs further, but still well below 1 percent of GDP for most countries (and on average much less than 1 percent). Note that these numbers are based on a period (1998-2007) that excludes the worst months of the crisis, so that actual benefits of the latter strategy are likely to be smaller.
} 
Although some of the pull-out from (foreign) non-government assets was driven by a need to intervene to support the domestic currency or to employ reserves to alleviate the foreign currency needs of the domestic banking sector, it was primarily the fear of losing (more) money that drove reserve managers back into safe investments. Overall reserve levels did not decline much and, as we show in the next section, central banks actually using the reserves were a minority. Again, from the RMT 2009 survey: "Reserve managers reveal great concern about credit and liquidity risks," and "Reserve managers became nervous as even traditional safe havens were blighted by spells of illiquidity."

In retrospect, the diversification strategies were ill-timed, as many central banks appear to have started or intensified their search for yield when spreads were narrow, and exited after spreads had widened (see in particular Figure 4). In most cases, the financial consequences of these decisions turned out to be mild, as positions were simply held to maturity, and cash was reinvested elsewhere (the semi-active approach discussed above). Very few central banks faced an actual default on e.g., deposits in their portfolio, but it is not difficult to imagine a less favorable outcome. Central banks having to (actively) sell non-traditional securities to finance support measures, had to do so at depressed prices and in illiquid markets. On those assets, the central bank probably had to accept a loss - although the magnitude obviously depended on the prices at which the assets had been purchased - but these were typically offset by large positive returns on (larger) government bond portfolios.

Whether central banks will return to their diversification strategies any time soon remains to be seen. A central banker's utility function, as well as public scrutiny, is very asymmetric: the rewards from high returns are much smaller than the negative consequences of having to report losses. The conclusion from RMT 2009 that "there is little evidence of future appetite for diversification into new currencies or asset classes" is therefore hardly surprising.

\section{B. Magnitude of the Risk Reduction}

\section{Data Sources}

Data on central banks' asset allocations and risk management frameworks are scarce. Only a few central banks are fully transparent in the reporting of their reserve management operations, including currency composition and detailed asset allocation covering, for example, credit quality information. It is therefore impossible to get a complete picture of the magnitude of the risk reduction by reserve managers from central bank reporting. We have collected information from various sources that are conclusive for the subsets covered and sufficiently large to make indicative estimates of the central banking community as a whole.

The most extensive and consistent dataset available on reserve levels and composition is collected by the IMF. This dataset consists of reserve data from countries that voluntarily subscribe to the Special Data Dissemination Standard (SDDS) and report the data according to a common template. These data are available at websites in the subscribing countries but also conveniently combined at the IMF's SDDS portal. At the end of 2009, 63 countries plus 
the ECB and the Eurosystem report according to the template, representing roughly half of overall world reserves. ${ }^{10}$

The SDDS reserves template breaks down the core holdings of official reserve assets into (1) foreign currency reserves (in convertible foreign currencies), (2) an IMF reserve position, (3) SDRs, (4) gold, and (5) other reserve assets. We focus on (1), which is further broken down into securities and deposits, which are yet further categorized as deposits at (i) other national central banks, the Bank for International Settlements (BIS) and IMF, and (ii) commercial banks. ${ }^{11}$

We also use data from the Treasury International Capital (TIC data) System, the BIS International Banking Statistics, and central bank websites.

\section{Bank Deposits}

Figure 6 sums all official reserves reported by SDDS subscribers that are held as (uncollateralized) commercial bank deposits, both in absolute terms (all currencies) and as a share of total reserves. ${ }^{12}$ As can be seen, prior to the crisis there was a clear upward trend in the level of deposits at commercial banks, primarily driven by growing reserves: the percentage share of deposits was essentially flat in the 18 months preceding the crisis. ${ }^{13}$ The trend in the level of reserves held as deposits changed abruptly around August 2007, widely associated with the beginning of the global financial crisis. After Lehman Brothers' collapse in September 2008, the speed at which reserve managers withdrew their deposits increased: in the two months following Lehman Brothers' collapse alone an amount equivalent to almost US $\$ 170$ billion was pulled out of deposits.

Between July 2007 and March 2009, the overall share of commercial bank deposits in the reserves of SDDS subscribers dropped 12 percentage points, corresponding to an absolute amount of over US $\$ 350$ billion. ${ }^{14}$ After March 2009, deposits continued to decline, although at a slower pace.

\footnotetext{
${ }^{10} \mathrm{See}$ http://www.imf.org/external/np/sta/ir/colist.htm for a list of reporting countries. Data for the Eurosystem as a whole are not used, in order to avoid double counting with data from individual countries already included in the set.

${ }^{11}$ (2)-(4) are typically driven by other factors beyond the influence of reserve managers. (5) includes markedto-market financial derivatives, loans to non-bank non-residents, and repo assets that are liquid and available upon demand. Given that for many countries in the sample a breakdown is not reported, we analyze net repos from other parts of the SDDS separately.

${ }^{12}$ In order to avoid a break in the series, Figure 6 excludes one country that started reporting to SDDS during the crisis.

${ }^{13}$ A part of the increase in absolute levels is attributed to a weakening of the U.S. dollar.

${ }^{14}$ Including one country that started reporting during the period of observation.
} 
Figure 6. Central Bank Reserves Held as Bank Deposits

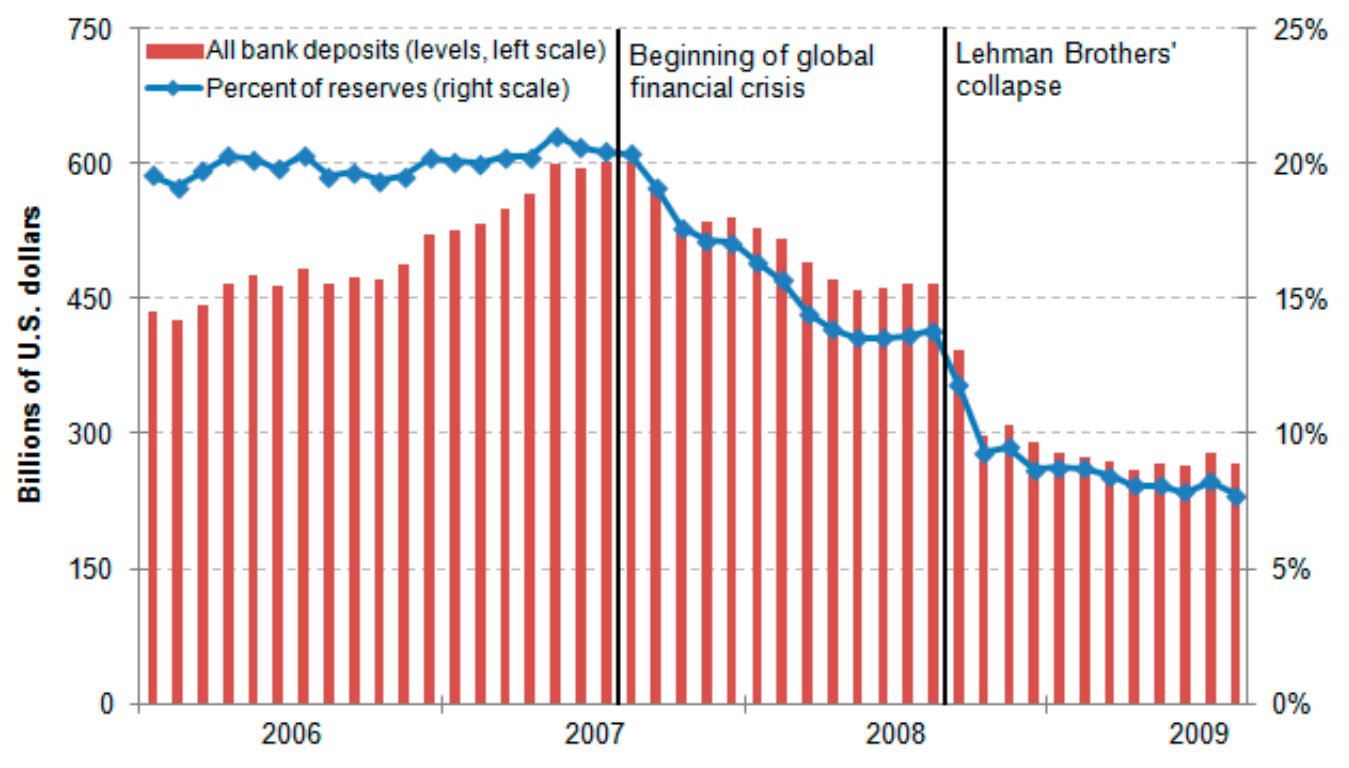

Source: IMF, Special Data Dissemination Standard.

Although the decline in total amount was somewhat dominated by a few large reserve holders, the pattern was similar in the vast majority of the central banks in our dataset. As can be seen from Figure 7, only 15 percent of the central banks that held deposits did not reduce the allocation during the crisis in a meaningful amount. In contrast, 43 percent reduced the share of bank deposits by more than 20 percentage points from peak to through between July 2007 and March 2009, and for over two-thirds the decline was more than 10 percentage points. Several central banks pulled out all their deposits at some point during the crisis; nearly 80 percent of the sample reduced their deposits by more than half. ${ }^{15}$

Figure 8 zooms in on the central banks that reduced deposits, and compares the deposit reduction with the change in reserves. For each central bank, we calculate the maximum reduction in deposits during the crisis, and find the corresponding change in reserves over the same period. We normalize the changes by the initial reserve levels at the period of the peak in deposits. The relative changes are plotted in a scatter diagram. The diagonal in Figure 8 represents those central banks that saw reserves drop as much as deposits; in other words, this line represents central banks that reduced deposits because they needed to spend the reserves (aside from some valuation changes). Only a few central banks reduced deposits by less than the reduction in reserves - the area to the right of the diagonal. The vast majority of central banks reduced their deposits far more than the change in their reserves. In fact, many central banks actually saw reserves increase as they pulled out of bank deposits. This is a

\footnotetext{
${ }^{15}$ To illustrate this point, we calculate minimum and maximum share of deposits in reserves between July 2007 and March 2009 and only measure the difference if the peak precedes the trough, which did not occur for nine central banks. These are categorized as not having shown a clear reduction in the share of deposits.
} 
clear indication that the deposit reduction was driven by a change in the risk assessment or risk tolerance of these central banks.

\section{Figure 7. Distribution of the Decline of Bank Deposits as a Share of Reserves}

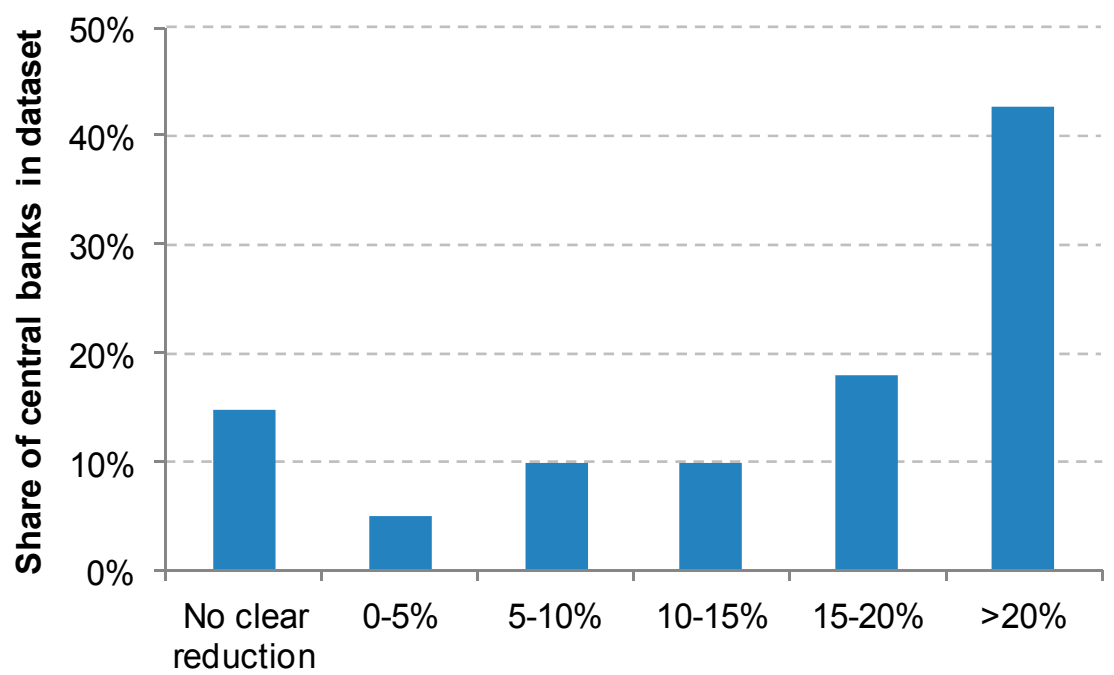

Reduction in deposit share

Source: IMF, Special Data Dissemination Standard.

Figure 8. Change in Bank Deposits vs. Change in Reserves

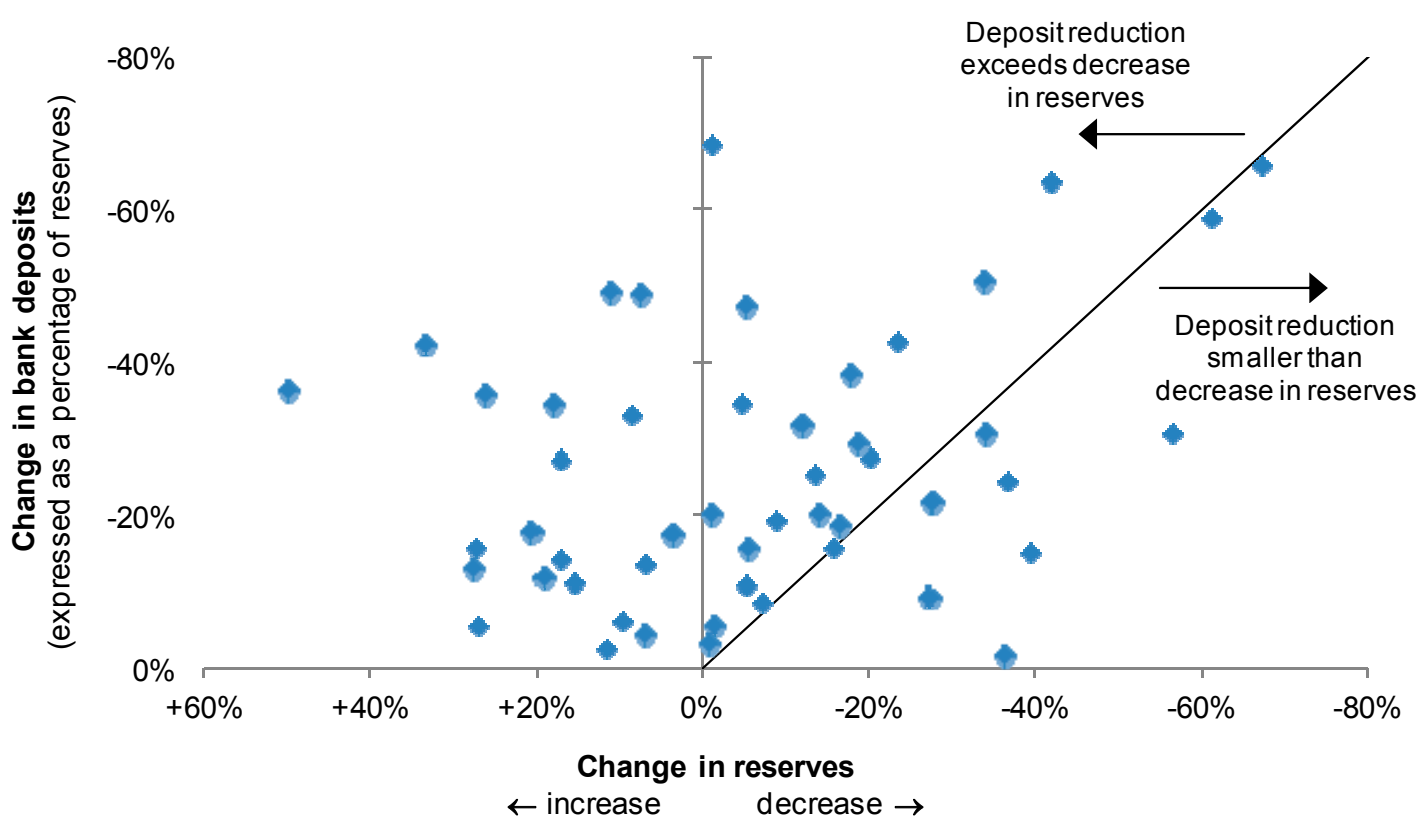

Source: IMF, Special Data Dissemination Standard. 


\section{Repurchase Agreements (Repos)}

We consider the possibility that reserve managers simply replaced uncollateralized deposits with collateralized deposits, through reverse repos (technically, a buy and a sell back of a security). This point was raised with us in several discussions with reserve managers, who argued that the reduction in deposits overestimates the impact on liquidity conditions in the banking sector.

Figure 9 shows that, starting in December 2007, some of the decline in deposits was indeed offset by an increase in net repos. ${ }^{16}$ This pattern continued and actually more than offset the decline in deposits until the collapse of Lehman Brothers, when a sharp decline in net repos occurred too (US\$124 billion from end-September to end-December 2008). Over the entire crisis period of July 2007 - March 2009, net repos declined by over US $\$ 40$ billion in the dataset.

\section{Figure 9. Central Bank Reserves Invested in Bank Deposits and Reverse Repos}

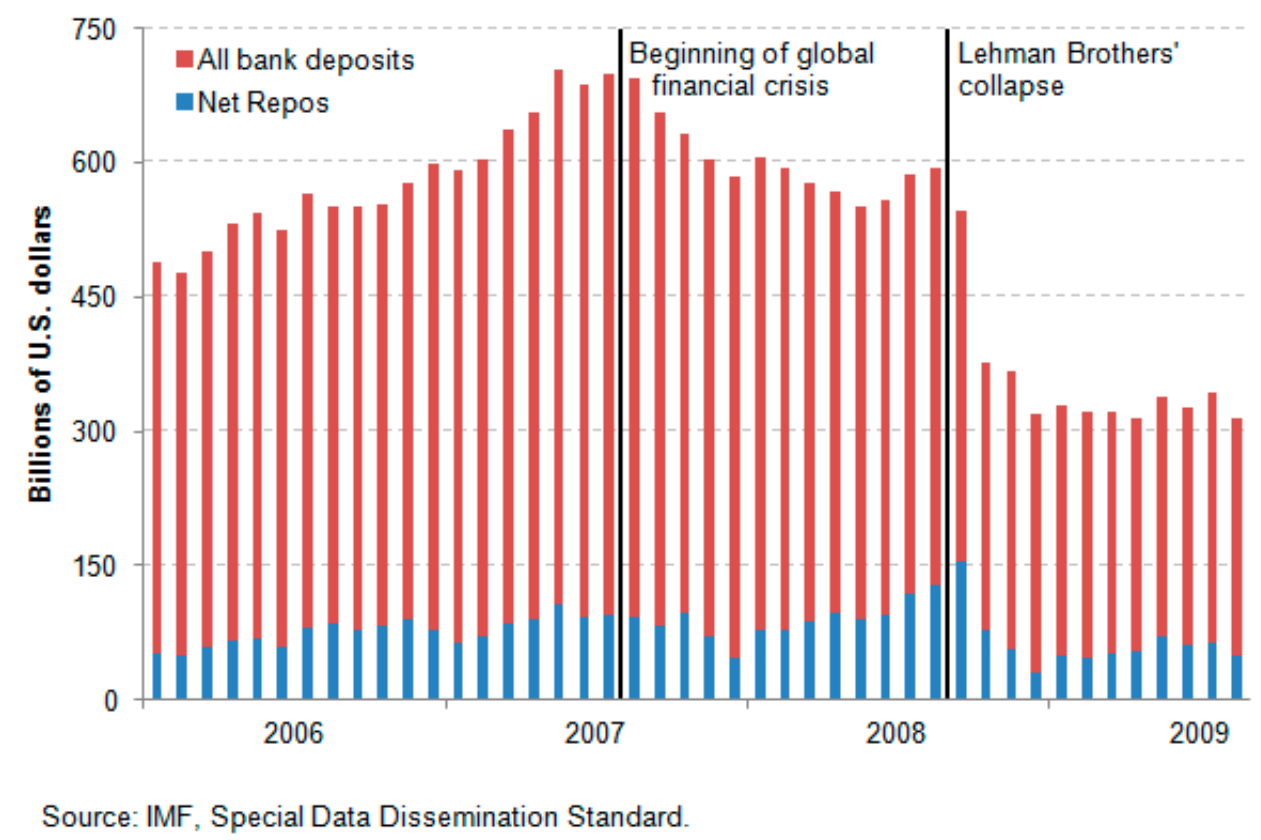

\footnotetext{
${ }^{16}$ The reserve template allows for variation on how repos are accounted for depending on whether they are considered as official reserve assets or other foreign currency assets. Given this and some lack of consistency in reporting the repos in SDDS, in Figure 9 we use the overall amounts from the Memo Section (IV) of the template that include all repos regardless of the treatment in Section I.
} 


\section{Overall Reduction in Banking Sector Exposure}

The SDDS reserves template does not break down the data on securities. This item includes government securities, as well as non-government securities such as agencies, certificates of deposit and commercial paper of the banking sector, among other things. For this reason, it is not possible to extract information from the database on the pullback of tradable bank securities by reserve managers. TIC data, however, show that official holdings of U.S. treasuries increased dramatically during the crisis, suggesting that most if not all of the increase in securities was in government securities.

Another relevant data source, the BIS International Banking Statistics database, is based on the reports of commercial banks - counterparties of central banks - from 41 countries on cross-border claims and liabilities, broken down into various dimensions. According to these quarterly data the cross-border liabilities of the reporting banks to "official monetary authorities" fell by over US\$420 billion from June 2007 to March 2009. ${ }^{17}$

The SDDS data also show that there was a slight increase (US\$68 billion between July 2007 and March 2009) in reserves held as deposits with other central banks and the BIS, some of which could have been channeled back to the banking sector. However, the BIS itself actually decreased its exposure to the banking sector by SDR 92 billion, corresponding to over US\$140 billion, between March 2008 and March 2009. ${ }^{18}$

Overall, data limitations lead to some uncertainty over the precise estimate of the total reduction in banking sector exposure by central banks and the BIS. However, we can conservatively estimate that the pullback has been more than the equivalent of US\$500 billion during the crisis, the majority of which occurred immediately after Lehman Brothers' collapse. The majority of this money was invested in safe-haven assets, i.e., predominantly in government bills and bonds. A smaller share was deposited with the central banks in reserveissuing countries.

\section{Agencies}

Agency debt became especially popular among central banks in the past decade, when reserves were diversified out of government securities. According to the TIC data, official holdings of U.S. agency debt increased more than tenfold from March 2000 to June 2008,

\footnotetext{
${ }^{17}$ According to these data, liabilities to the official monetary authorities increased until December 2007, when they peaked at US\$1,442 billion and fell to US\$935 billion in March 2009—a reduction of roughly US\$500 billion.

${ }^{18}$ We convert the change in SDR exposure into US\$ using an average SDR/US\$ exchange rate over the period March 2008-09. According to BIS (2009), these changes reflect concerns over the rising risk in the BIS' balance sheet. The BIS aims to maintain superior credit quality by adopting a prudent approach to risk management, which includes inter alia maintaining an exceptionally strong capital position, investing predominantly in high credit quality financial instruments, seeking to diversify across a range of sectors, and maintaining a high level of liquidity. The BIS invests directly as an external manager for other central banks and indirectly through intermediating central bank deposits and investments at the BIS.
} 
compared with a roughly fourfold increase in reserves. In June 2008, official holdings in agencies peaked at US\$966 billion, after which central banks and other official sector investors started to divest out of U.S. agencies, amidst concerns of their credit quality. Between July 2008 and March 2009 the official sector reduced its holdings of U.S. agency securities by over US\$93 billion. This happened while the U.S. authorities undertook massive support measures to avoid default of the agencies, culminating in Fannie Mae and Freddie Mac being placed under the conservatorship of the Federal Housing Finance Agency in early September 2008. Setser (2008) summarizes the behavior of reserve managers as follows: "The general flight out of risk by central banks is one reason why the Treasury's bailout of the Agencies has failed to halt the central bank run on Agencies."

\section{Procyclicality in Credit Limit Frameworks}

Reserve managers typically operate within a risk control framework that defines, among other things, eligibility criteria and credit limits for counterparties or issuers. Many of these frameworks rely heavily on external ratings, as central banks typically lack resources to do in-depth credit analysis in-house. Limits are inversely related to the creditworthiness - often approximated by a rating - of a counterparty or an issuer. This set-up has some inherent procyclical elements, even if ratings are calibrated to be "through-the-cycle."

It is therefore plausible that the withdrawal of central bank investments from the banking sector was, at least partly, driven by rating downgrades, in combination with a strict enforcement of a (stable) risk control framework, rather than by a sudden rise in risk aversion. ${ }^{19}$ It is unfortunately not possible to quantify the contribution of the risk control framework at the aggregate level, because the details of most frameworks are not publicly available. Even in the few cases where detailed information about the framework is public — such as the framework of the ECB (Manzanares and Schwartzlose, 2009) — some key parameters for the calibration of limits are unavailable. ${ }^{20}$ Strong assumptions are needed to estimate the impact of rating changes on limits and, ultimately, positions.

Based on some crude, back-of-the-envelope calculations, we estimate that between their peak at end-2007 and end-2008, changes in aggregate credit limits may explain a reduction of bank exposure of around 10 percent. ${ }^{21}$ Note that this estimate is relevant only if the limits had

\footnotetext{
${ }^{19}$ Bindseil (2009) introduces the "inertia principle of risk management," arguing that during a crisis a central bank should maintain its risk control framework (at least) inert, and accept that risks may increase considerably as a consequence.

${ }^{20}$ In the framework of the ECB, credit limits are a function of rating and capital, reflecting that the maximum exposure to a counterparty or issuer should be linked not only to its creditworthiness, but also to its size. The function is linear in a numerical "equivalent" of the "second-best" rating, and piecewise linear in capital, with a kink that differentiates between large and small counterparties. To calibrate the limits, one would need to know, among other things, the median capital of eligible counterparties, which is not publicly available.

${ }^{21}$ This calculation is based on the ECB framework and a sample of the ten largest banks, sorted by total assets in U.S. dollar at year-end 2008 (except in case of an accounting cycle not based on a calendar year), as published by the Bankers Almanac. In applying the ECB framework, we have (conservatively) set the median capital to zero. With different a assumption, the estimated attribution to the framework becomes smaller. The
} 
been fully utilized before their reduction, and if no other limits - in particular concentration limits - had been in place. This is highly unlikely, so that the actual contribution of risk management frameworks has most probably been substantially smaller. Given that the actual pullback was around 50 percent, we must conclude that the pullback was to a large extent driven by other factors, including in particular active and semi-active risk reduction by reserve managers. ${ }^{22}$

\section{LIQUIDITY SUPPORT FOR THE BANKING SECTOR}

During the crisis many central banks embarked on extraordinary measures to counter the effects of the crisis, especially to provide liquidity to the banking sector. These took the form of increasing the volume and widening the scope of lending-longer maturities, adding foreign currencies, and relaxing the collateral requirements - as well as asset purchase programs. Examples of the latter include purchases of agency debt by the Federal Reserve (Fed) and of covered bonds by the Eurosystem. ${ }^{23}$

We focus on the increase in the volume of central bank lending to the banking sector. A detailed discussion is beyond the scope of this paper, but in order to get an idea of the timing, magnitude, and concentration, as well as the potential interplay with reserve managers' actions, we approximate the liquidity injections by using the monthly changes in central banks' (or monetary authorities') claims on domestic banks and other depository corporations in Figure 10. The data are from the International Finance Statistics database of the IMF and cover 176 central banks and monetary authorities. ${ }^{24}$

Figure 10 shows a time series of changes in central bank lending to domestic depository corporations. Support measures remained fairly modest in size until late 2007, when the ECB announced extra facilities to ensure liquidity over the year-end (European Central Bank,

impact of the (undisclosed) frameworks at other central banks may have been somewhat larger, as many others use only ratings, but not capital to determine limits. In 2008, aggregate capital of the banks in the sample actually went up, offsetting some of the impact of rating downgrades in the ECB limit framework. Without capital, the limit reduction would therefore have been larger. The two approximations - unknown parameter in the ECB model and absence of capital in the framework of many others - work in opposite directions. It is impossible to tell which one dominates, as it is impossible to estimate the impact of other unknown factors, e.g., possible non-linearity of the rating factor in other models. All in all, though, it seems reasonable to assume that these approximations largely offset each other.

22 The limited contribution of automatic triggers is hardly surprising given that ratings are through-the-cycle and capital is updated infrequently and with delays. In particular, in our sample of the ten largest banks, only three experienced a downgrade by more than one notch in their second-best rating. Also over a longer period, the distribution of investment grade ratings appears fairly stable (Standard \& Poor's, 2010, Chart 5).

${ }^{23}$ See e.g., Borio and Disyatat (2009) for a discussion of these unconventional measures.

${ }^{24}$ The most notable country missing in this dataset is the United Kingdom. The data on the Bank of England website suggest that its additional liquidity injections over the two months after Lehman Brothers' collapse totaled about US\$170 billion. 
2007b). Most of this liquidity was withdrawn in January 2008. The first larger spike in liquidity injections that was not immediately reversed occurred after the near-collapse of Bear Stearns, but it pales in comparison with the two months following Lehman Brothers' collapse in September 2008.

Figure 10. Liquidity Measures Approximated by Changes in Central Bank Claims on the Domestic Banking Sector

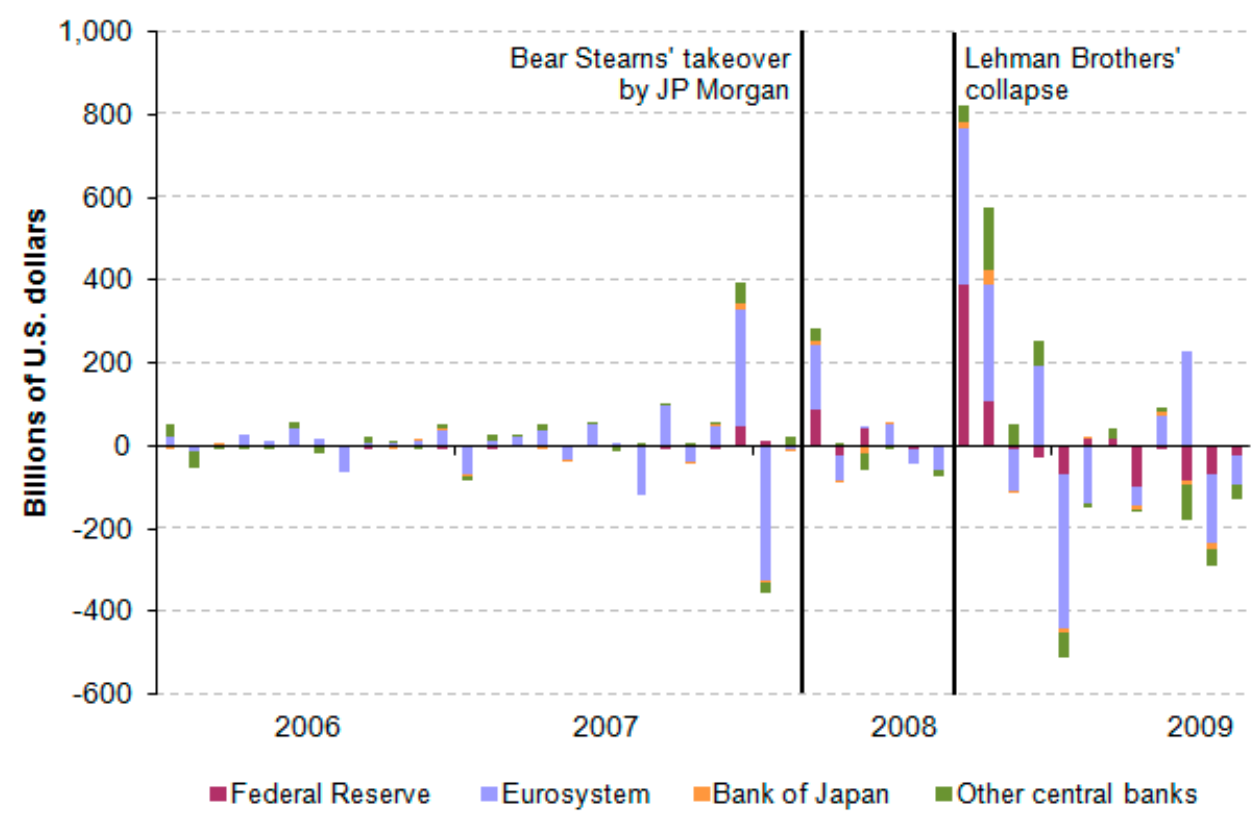

Source: IMF, International Financial Statistics.

Another notable aspect in Figure 10 is concentration - about 93 percent of the first month's increase in banking sector claims after Lehman's collapse is supplied by Eurosystem central banks (blue bars) and the Fed (red bars). The Bank of Japan (orange bars) and other central banks (green bars) only account for a fraction of the initial increase, but have a greater share of the total the following month with the central banks of Canada and Sweden accounting for more than half of the increase in the green bar.

Note that Figure 10 does not break down the currency in which liquidity was provided to the banking sector. A large proportion of the liquidity provided by central banks was in foreign currency (mainly U.S. dollar), facilitated by swap lines (or Reciprocal Currency Arrangements) between the Fed and other major central banks. ${ }^{25}$ The net dollar amount outstanding through dollar swaps peaked at nearly US $\$ 600$ billion at the end of 2008 (Goldberg, Kennedy, and Miu, 2010).

\footnotetext{
${ }^{25}$ See e.g., McGuire and von Peter (2009) for a good description of the network of central bank swap lines during the crisis.
} 
In total the central banks (mainly the Fed and of the Eurosystem) can be estimated to have injected at least US\$1.8 trillion of additional liquidity into the banking sector over the four months following Lehman Brothers' collapse. This estimate, however, excludes direct purchases of private and government securities, which were resorted to at a later stage in the crisis, mainly for quantitative easing or supporting the functioning of particular markets.

Some of this liquidity support was needed to offset the money withdrawn by other central banks, which, as discussed in the previous section, added up to at least US\$500 billion. Although not the full US\$500 billion needed to be offset - most was reinvested in treasuries and thus stayed in the system - the withdrawal of central bank deposits was significant, not least because it contributed to a reallocation of funds from weaker to stronger banks. Other factors, not captured in our calculation, such as the shortening of maturities of deposits, also contributed to the stress in the system, and thus demanded a stronger policy response from, in particular, the Fed and the Eurosystem.

\section{Reserve Management ANd Financial Stability}

While central banks took bold and drastic measures to weather the global financial crisis, central bank reserve managers in other countries, and sometimes even in their own, acted in ways that partially offset support measures for the financial sector. Although clearly not the main cause, the funding problems of the banking sector were compounded when a previously reliable source of funding - central bank reserves - suddenly disappeared. ${ }^{26}$ Other sources of funding dried up simultaneously or were available only at increasingly penalizing spreads. Moreover, until collateral requirements were relaxed, banks with insufficient high-quality collateral had limited access to central bank financing through normal open market operations. In response, banks had to tighten their lending conditions, thus affecting the real economy.

The most direct and significant contribution to the instability was the sharp and abrupt reduction in reserves held as bank deposits, discussed in detail in Section IV. Figure 11 compares the monthly reduction in deposits with the 3-month LIBOR - OIS spread, as an indicator of funding pressures in the interbank market. The spikes in the LIBOR - OIS spread, in particular the one following the collapse of Lehman Brothers, demonstrate that interbank funding, even for highly-rated banks at relatively short maturities, became very expensive. For banks with lower ratings, or for longer maturities, the market dried up completely. As the figure clearly shows, these episodes generally coincided with reductions in central bank deposits in the financial sector.

\footnotetext{
${ }^{26}$ McGuire and von Peter (2009) highlight that commercial banks were generally exposed to considerable funding risk, because most of their funding was short term (from central banks, interbank markets, and FX swaps). When heightened credit risk compromised these sources, the chronic U.S. dollar funding needs became acute, particularly in the wake of Lehman Brothers' bankruptcy. Although central bank deposits typically were short term, they had become a fairly stable source of funding for commercial banks, as deposits were typically rolled over often automatically. Therefore, we argue that the drying up of this source may have caught banks more off-guard than the drying up of interbank markets, which is more typical of a liquidity crisis combined with credit concerns.
} 
Figure 11. Deposit Reduction vs. LIBOR - OIS Spread

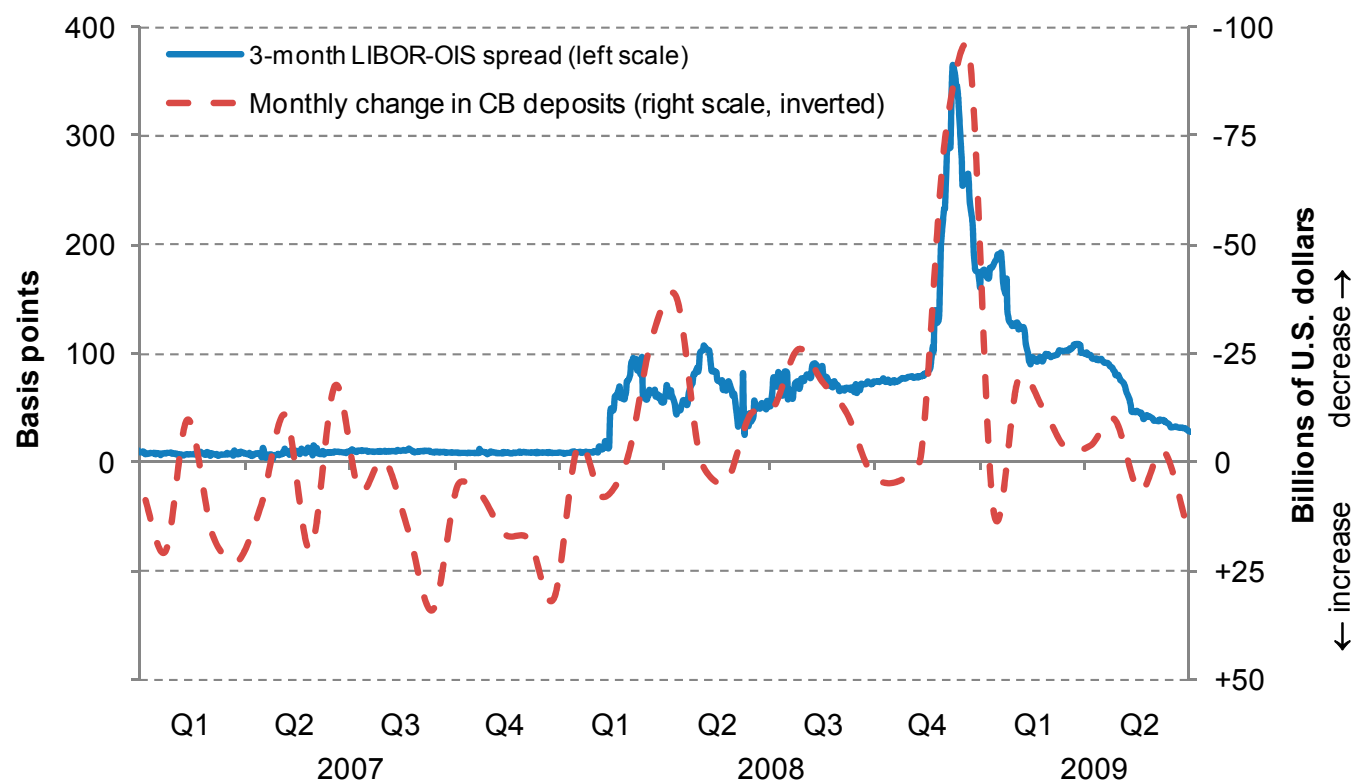

Sources: Bloomberg (for spreads); IMF, Special Data Dissemination Standard (for change in deposits).

A second, less direct channel was the sale of bank securities - certificates of deposit, commercial paper, covered bonds, and even equities - held by several central banks. This happened in much smaller volumes, because positions were much smaller ${ }^{27}$ and because markets had become illiquid when the need to sell arose. Moreover, as these securities were sold to other investors, the transactions did not affect bank funding directly. Still, additional supply put further downward pressure on the prices of these securities, ultimately increasing funding rates as well.

Reserve management can affect markets in a third way because its actions may have adverse and unintentional signaling effects to market participants. These signaling effects may occur even if transactions are small, as central banks' investment activities are closely monitored. IMF (2001) mentions potential signals on monetary and exchange rate policies coming from reserve management activities. It is also possible that actions signal a lower risk tolerance at the central bank, or concerns about particular counterparties or issuers. An example is the rumor that spread in mid-2003 that the ECB was eliminating its exposure to Fannie Mae and Freddie Mac (see Bloomberg, 2003). Signals are more likely to come from active trading with a third party than from holding a position until maturity. Still, even changes in deposits can be monitored, albeit with a time lag and aggregated over counterparties, from the same banking statistics that we use in Section IV.

\footnotetext{
${ }^{27}$ See, for instance, Wooldridge (2006), table 3, who shows that only a very small fraction of official institutions' investments in U.S. securities is held in non-treasury, non-agency debt.
} 
Signaling can lead to instability if markets - rightly or wrongly - conclude that the central bank has superior information about the market, or about a counterparty, and other market participants adjust their positions accordingly. Figure 11 suggests there is not much evidence that changes in the composition of central bank reserves triggered a sell-off by other investors during the crisis. If anything, it was the opposite: when the first signs of turbulence emerged in mid-2007, reserve managers were relatively late to reduce their exposures (although they reacted more quickly in subsequent phases of the crisis). ${ }^{28}$

It appears that many central banks were aware of the potential conflict between risk reduction and financial stability. As early as August 2007, ECB President Trichet called "on all parties concerned to continue to keep their composure" (European Central Bank, 2007a). His verbal intervention clearly echoed concerns that if market participants, central banks included, started to reduce their exposures, their actions might exacerbate the problems of the financial sector. ${ }^{29}$ The RMT 2009 survey (conducted in late-2008) asked reserve managers: "Do you think the market turmoil has highlighted a potential for policy conflict within central banks as monetary policy aims to inject liquidity into the banking system, and reserve management tries to reduce exposures to protect reserves?", to which approximately half of the respondents (19 out of 37) replied affirmatively. In various discussions with reserve managers, we learned that several of them would have liked to have held on to their positions and accepted the larger risk, if only they had been assured that their peers would do the same. Peer pressure, in combination with the fear of being the last one to reduce exposure, thus seems to have created a "prisoner's dilemma" and, hence, a sub-optimal equilibrium.

The adverse impact on markets was compensated, at least locally, if the central banks used the proceeds to support domestic markets, but, as argued before, this was the case in only a minority of countries. More importantly, even if these central banks were successful in improving domestic conditions, they did so at the expense of other countries, notably those issuing reserve currencies. Nugée (2000) formulates the issue very clearly: "a central bank should always manage its reserves in such a way that it does not destabilise markets, ... or hinder another central bank's operations or objectives." It is no surprise that the Fed and the Eurosystem had to counteract a lot more aggressively than their local problems alone could explain. In this regard, being able to issue a global reserve currency seems to come not only with widely touted "exorbitant privileges," but also with costs and risks attached to it.

\footnotetext{
${ }^{28}$ Figure 11 appears to suggest that central banks were perhaps a tad faster than rest of the market around the time Lehman Brothers collapsed, but this is just because the line displaying the deposit reduction is based on monthly data, whereas the spread is based on daily observations.

${ }^{29}$ Around the same time, Buiter (2007) addressed the (monetary policy function of) central banks more specifically: "Dealing with a liquidity crisis and credit crunch is hard. Inevitably, it exposes the central bank to significant financial and reputational risk. The central banks will be asked to take credit risk (of unknown magnitude) onto their balance sheets and they will have to make explicit judgments about the creditworthiness of various counterparties. But without taking these risks the central banks will be financially and reputationally safe, but poor servants of the public interest." At a later stage in the crisis Borio and others (2008), Jordan (2008), and González-Páramo (2009), among others, also sketched the dilemmas and trade-offs in various forums.
} 
The behavior of reserve managers raises questions about central bank governance. Most central banks engage in some form of active reserve management, with responsibility for daily portfolio management delegated to lower levels in the organization. Reserve managers operate within a framework with upper bounds on credit exposure, but typically without lower bounds. A relevant question therefore is whether the risk reduction was the decision of reserve managers responding to incentives - avoiding losses, outperforming a benchmarkwith senior management informed only after the fact, or whether these decisions were made at the highest level of the central banks, perhaps in response to the fear of reputation damage from having to report a loss. There is no publicly available information on this, but through our contacts at central banks we know that both have happened. In the former case, it may be relatively easy to deal with procyclical behavior, for instance by realigning incentives of reserve managers with financial stability, or through introducing passive reserve management for certain asset classes. The latter-more difficult — case may require more international coordination between central banks.

The crisis has important lessons for the strategic asset allocation and reserve management activities of central banks. Some asset classes and investment strategies are much more prone to procyclical reserve management than others. Credit is by nature a very procyclical asset class, and would therefore belong only, if at all, in the portfolios of central banks with ample reserves and capital, who can and are willing to hold their positions through the cycle. If reserves are actively managed, a reserve manager will have an incentive to reduce exposure -i.e., act procyclically_when facing a crisis or simply a higher risk of default. ${ }^{30}$ This is true even if credit is also included in the strategic benchmark. In many cases, it may be best to avoid credit exposure altogether, or at least reduce the allocation to credit substantially.

Going forward, countercyclical assets deserve a more prominent role in central bank reserves, even if their return in normal times may be somewhat lower than the return on procyclical assets. As we have recently shown (Pihlman and van der Hoorn, 2009, and forthcoming Working Paper), a somewhat longer (3-5 year) duration strategy in high-quality liquid government bonds may be an attractive alternative to credit. This strategy has two benefits over a long-credit strategy. First and foremost, a reserve manager selling high-quality longerdated government bonds during a systemic crisis acts countercyclically, as the market is trying to buy the same securities in a flight to quality. Secondly, for the same reason, the reserve manager is likely to get a good price for these bonds, offsetting some, although perhaps not all, of the yield give-up vs. credit in normal times. ${ }^{31}$ More importantly perhaps, the reserve manager would not be under pressure to sell the security as soon as possible. The financial stability objectives of the central bank and the narrowly defined objectives of the reserve manager are thus closely aligned.

\footnotetext{
${ }^{30}$ See Nugée (2000) or Bindseil (2006) for arguments why central banks may opt for active reserve management.

31 The most direct way to benefit from a high price is to sell a security. Alternatively, a reserve manager, who doesn't need to or want to sell, could lend the bond and benefit from special repo rates for the bond. We note, though, that the repo market did not function properly in the midst of the crisis.
} 


\section{Conclusions}

When the global financial crisis started in 2007, the composition of central bank reserves was riskier than ever before, following a decade-long diversification process. During the crisis many central banks joined the flight to quality, and acted procyclically by reducing their exposure to the banking sector and agencies in their reserves. We estimate that reserve managers pulled out at least the equivalent of US\$500 billion of deposits and other investments from the banking sector, mainly in an effort to protect their investments from default risk. At the same time, and peaking in the months after Lehman Brothers' collapse, central banks - in particular the Fed and of the Eurosystem - provided unprecedented liquidity support to the banking sector, in order to stabilize the system.

The crisis has brought to the fore the linkages between reserve management and financial stability. Even if it could be argued that reducing risk in reserve portfolios in anticipation of liquidity support is good risk management, the associated signaling and financial stability implications are problematic, also from an individual central bank's point of view. By focusing on the (default) risk for their own assets, reserve managers transferred the burden for preserving financial stability and rescuing the financial sector to other central banks, notably the Fed and Eurosystem central banks. The crisis has thus demonstrated that issuing a reserve currency comes not only with "exorbitant privileges," but with risks and potential costs as well. More international coordination between central banks may be needed to address these issues.

The linkages with financial stability have important implications for the strategic asset allocation and reserve management activities of central banks. Credit is a very procyclical asset class, which should probably have a much less prominent allocation in central bank reserves, and ideally be replaced by countercyclical assets. This way, the financial stability objectives of the central bank and the incentives of reserve managers can be more closely aligned.

As the crisis enters a new-sovereign - phase, it would be interesting to analyze how reserve management responds. Recent rumors - quickly denied — of central banks selling euros or euro-denominated government debt could also be interpreted as procyclical investment behavior. The conclusions drawn in this paper on the role of credit in reserve portfolios do not necessarily apply to currencies or sovereign debt. Data on securities holdings are more limited, but the next phase of the crisis raises important new questions for reserve management that are worth follow-up studies. 


\section{REFERENCES}

Amato, Jeffery D. and Eli M. Remolona, 2003, “The Credit Spread Puzzle,” BIS Quarterly Review 12, pp. 51-63.

Bakker, Age F.P. and Ingmar R.Y. van Herpt, 2007, Central Bank Reserve Management: New Trends, from Liquidity to Return (Cheltenham: Edward Elgar).

Bindseil, Ulrich, 2006, “Active Portfolio Management by Central Banks: Why and How?" in Institutions in Perspective, ed. by Ulrich Bindseil, Justus Haucap, and Christian Wey (Tübingen: Mohr Siebeck).

Bindseil, Ulrich, 2009, "Central Bank Financial Crisis Management," in Risk Management for Central Banks and Other Public Investors, ed. by Ulrich Bindseil, Fernando González, and Evangelos Tabakis (Cambridge: Cambridge University Press).

BIS, 2009, "79th Annual Report,” available at http://www.bis.org/publ/arpdf/ar2009e.htm.

Bloomberg, 2003, "ECB Recommends Central Banks Sell U.S. Agency Debt, Person Says," July 28.

Borio, Claudio and Piti Disyatat, 2009, "Unconventional Monetary Policies: An Appraisal," BIS Working Papers, No 292.

Borio, Claudio, Jannecke Ebbesen, Gabriele Galati, and Alexandra Heath, 2008, "FX Reserve Management: Elements of a Framework,” BIS Papers, No 38.

Borio, Claudio, Gabriele Galati, and Alexandra Heath, 2008, "FX Reserve Management: Trends and Challenges," BIS Papers, No 40.

Bourquin, Hervé and Roman Marton, 2009, "Performance Measurement," in Risk Management for Central Banks and Other Public Investors, ed. by Ulrich Bindseil, Fernando González, and Evangelos Tabakis (Cambridge: Cambridge University Press).

Buiter, Willem, 2007, “The Central Bank as Market Maker of Last Resort 1,” Maverecon Blog, August 12, available at http://blogs.ft.com/maverecon/2007/08/the-central-banhtml/.

Carver, Nick and Robert Pringle, 2009, "Trends in Reserve Management-2009 Survey Results," in RBS Reserve Management Trends 2009, ed. by Robert Pringle and Nick Carver (London: Central Banking Publications).

Congressional Budget Office, 2000, “The Budget and Economic Outlook: Fiscal Years 2001-2010," Washington (January).

European Central Bank, 2007a, "Statement by Jean-Claude Trichet," Press Release, August 14, available at http://www.ecb.int/press/pr/date/2007/html/pr070814 1.en.html. 
European Central Bank, 2007b, “The Eurosystem's Liquidity Management Measures Related to the Year-End 2007," Press Release, November 30, available at http://www.ecb.int/press/pr/date/2007/html/pr071130.en.html.

Fernandes, José Luiz Barros and José Renato Haas Ornelas, 2010, "Hidden Risks in MeanVariance Optimization: An Integrated-Risk Asset Allocation Proposal," in Interest Rate Models, Asset Allocation and Quantitative Techniques for Central Banks and Sovereign Wealth Funds, ed. by Arjan Berkelaar, Joachim Coche, and Ken Nyholm (New York: Palgrave Macmillan).

Goldberg, Linda S., Craig Kennedy, and Jason Miu, 2010, "Central Bank Dollar Swap Lines and Overseas Dollar Funding Costs," Federal Reserve Bank of New York Staff Report, No 249.

González-Páramo, José Manuel, 2009, "Managing Risk: The Role of the Central Bank in a Financial Crisis," Speech at Risk Europe, Frankfurt am Main, available at http://www.ecb.int/press/key/date/2009/html/sp090604.en.html.

IMF, 2001, "Guidelines for Foreign Exchange Reserve Management," available at http://www.imf.org/external/np/mae/ferm/eng/index.htm.

IMF, 2008, "IMF Intensifies Work on Sovereign Wealth Funds," IMF Survey Magazine, March 2008, available at http://www.imf.org/external/pubs/ft/survey/so/2008/POL03408A.htm.

Jordan, Thomas J., 2008, "Reserve Management and the Credit Crisis," Central Banking Journal, May, 18(4), pp. 45-49.

Kunzel, Peter, Yinqiu Lu, Iva Petrova, and Jukka Pihlman, "Investment Objectives of Sovereign Wealth Funds-A Shifting Paradigm," forthcoming in Economics of Sovereign Wealth Funds: Issues for Policy Makers, ed. by Udaibir S. Das, Adnan Mazarei, and Han van der Hoorn (Washington, D.C.: International Monetary Fund).

Manzanares, Andres and Henrik Schwartzlose, 2009, "Risk Control, Compliance Monitoring and Reporting," in Risk Management for Central Banks and Other Public Investors, ed. by Ulrich Bindseil, Fernando González, and Evangelos Tabakis (Cambridge: Cambridge University Press).

McCauley, Robert N. and Ben S.C. Fung, 2003, "Choosing Instruments in Managing Dollar Foreign Exchange Reserves,” BIS Quarterly Review, March, pp. 39-46.

McCauley, Robert N., "Choosing the Currency Numeraire in Managing Official Reserves," in RBS Reserve Management Trends 2008, ed. by Robert Pringle and Nick Carver (London: Central Banking Publications). 
McGuire, Patrick and Götz von Peter, 2009, "The US Dollar Shortage in Global Banking and the International Policy Response,” BIS Working Papers, No 291.

Nugée, John, 2000, "Foreign Exchange Reserves Management," Handbooks in Central Banking, No 19, Centre for Central Banking Studies, Bank of England.

Pihlman, Jukka and Han van der Hoorn, 2009, "Credit Risk vs. Duration: Lessons from the Financial Crisis for Reserve Management," Presentation at Joint BIS/ECB/World Bank Public Investors' Conference, November 16-17, 2009, Washington, D.C.

Pringle, Robert and Nick Carver, 2003, "How Countries Manage Reserve Assets-Summary of a Survey of Reserve Managers," in How Countries Manage Reserve Assets, ed. by Robert Pringle and Nick Carver (London: Central Banking Publications).

Pringle, Robert and Nick Carver, 2004, "Survey of Central Bank Risk Managers," in New Horizons in Central Bank Risk Management, ed. by Robert Pringle and Nick Carver (London: Central Banking Publications).

Pringle, Robert and Nick Carver, 2005, "Trends in Reserve Management-2005 Survey Results," in RBS Reserve Management Trends 2005, ed. by Robert Pringle and Nick Carver (London: Central Banking Publications).

Pringle, Robert and Nick Carver, 2007, "Trends in Reserve Management-2007 Survey Results," in RBS Reserve Management Trends 2007, ed. by Robert Pringle and Nick Carver (London: Central Banking Publications).

Ramaswamy, Srichander, 2008, "Managing International Reserves: How Does Diversification Affect Financial Costs?” BIS Quarterly Review, June, pp. 45-55.

Reinhart, Vincent and Brian Sack, 2000, "The Economic Consequences of Disappearing Government Debt," Brookings Papers on Economic Activity, 2, pp. 163-220.

Setser, Brad, 2008, "Central Bank Reserve Managers Still Are Running Away from Risk...," Council on Foreign Relations-Follow the Money Blog, November 2008, available at http://blogs.cfr.org/setser/2008/11/07/central-bank-reserve-managers-still-are-runningaway-from-risk/.

Standard \& Poor's, 2010, “2009 Annual Global Corporate Default Study and Rating Transitions," available to subscribers at http://www.standardandpoors.com/ratingsdirect.

Wooldridge, Philip D., 2006, "The Changing Composition of Official Reserves," BIS Quarterly Review, September, pp. 25-38. 